\author{
УДК 785.11.071.1(470) \\ DOI https://doi.org/10.31723/2524-0447-2021-32-1-15
}

Ганна Сергї̈вна Савченко

ORCID: 0000-0002-9845-0450

кандидат мистецтвознавства, доцент, доцент кафедри композиції та інструментування Харківського національного університету мистецтв

імені І. П. Котляревського lanna2@ukr.net

\title{
ОРКЕСТРОВЕ ПИСЬМО В ОПЕРІ «СОЛОВЕЙ» І. СТРАВІНСЬКОГО ЯК ЗАСІБ ОБ'ЕКТИВАЦЇ̈ ПРОСТОРОВО-ЧАСОВИХ ВІДНОСИН
}

Метою статті є дослідження прийомів оркестрового письма (як індивідуальної системи технологічних прийомів і принципів, спрямованої на об'єктивацію певних просторово-часових відносин у тембро-фактурній структурі твору) в опері I. Стравінського «Соловей». У роботі автор спирається на функціональний, компаративний, стильовий методи дослідження. Наукова новизна роботи полягає: 1) у дослідженні засобів оркестрового письма в опері «Соловей» у контексті стилістичного зламу; 2) у компаративному дослідженні прийомів оркестрового письма «Хмар» К. Дебюссі й I акту «Солов'я»; 3) у виявленні специфіки оркестрового письма в II та III актах опери як засобу об'єктивації просторово-часових відносин. Висновки. У I акті опери оркестрове письмо тяжіє до наслідування імпресіоністської техніки письма («Хмарu» K. Дебюссі), що виявляється у вибудовуванні просторової звукоматерії, стиранні межі між тлом та рельєфом, одночасному сполученні невеликої кількості різнофункціональних елементів; створенні континуальності за рахунок утримання фактури, тембрів та варіантної роботи з мотивами. Акцентується, що уже в межах I акту виявляє свою дію принцип багатофігурності. В оркестровій тканині II та II актів (після досвіду роботи в балеті) реалізується багатоелементність унаслідок застосування тембрових мікстів (часто інтонаційно-ритмічних варіантів), розщеплення оркестрових функцій, дії принципів багатофігурності та комплементарності, тематизації тла, що визначає складну організацію простору та формує високу подієвість часу. Деякі принципи оркестрового письма імпресіоністів розвиваються I. Стравінським оригінально згідно з індивідуально-стильовими настановами. У його оркестровиі знаходять продовження: 1) моделювання різноякісного оркестрового простору; 2) стирання межі між тлом та рельєфом, що є наслідком тематизації музичної тканини.

(C) Савченко Г. С., 2021 
Ключові слова: I. Стравінський; К. Дебюссі, опера «Соловей», «Хмари», оркестрове письмо, час, простір, багатофігурність.

Savchenko Hanna Serhiivna, Candidate of Art Criticism (PhD in Musicology), Associate Professor, Associate Professor at the Composition and Instrumentation Department of the Kharkiv National I. P. Kotlyarevsky University of Arts

Orchestral writing in the opera "The Nightingale" by I. Stravinsky as a tool to objectify spacetime relations

The aim of the article is to study principles of orchestral writing (that is individual system of technological devices and principles, aimed at objectivation of certain spacetime relations in timbral and textural structure of the work) in the opera "The Nightingale" by I. Stravinsky. In this research the author uses such methods as functional, comparative, stylistic. Scientific novelty of the article lies in the following: 1) in examination of orchestral writing in opera "The Nightingale" from the standpoint of stylistic turning point; 2) in comparative analysis of principles of orchestral writing in C. Debussy's "Nuages" ("Clouds")" and I act of "The Nightingale"; 3) in revealing of specifics of orchestral writing in the II and III acts of beforementioned opera as a tool to objectify spacetime relations. Conclusions. In the I act the orchestral writing inclines to follow impressionistic writing (C. Debussy's "Nuages"), which can be seen in creation of the spatial characteristic of the sound matter, obscuring the distinction between the relief and background, simultaneous usage of several elements bearing different functions, constructing of continuity through variant transfiguration of the motive invariants as well as by sustaining texture and timbres. It is stressed, that multi-figure principle functions from the I act. In the orchestral texture of II and III acts (written after acquiring experience of ballet composing) multi-elemental structure is applied, due to usage of timbre mixtures (often presented as rhythmical or intonational variants), splitting of orchestral functions, principle of multifigure composition and complementarity, thematization of the background, causing complex organisation of space and "dense" time, rich with events. Some principles of impressionistic writing are developed by I. Stravinsky in accordance with his individual stylistic beliefs. His orchestration shows further development of such principles, as: 1) modelling of heterogeneous sonic space; 2) obscuring of the border between the relief and background due to thematization of the musical texture.

Key words: I. Stravinsky, C. Debussy, opera "The Nightingale”, “Clouds”, orchestral writing, time, space, multi-figure composition.

Актуальність теми дослідження. Серед величезного корпусу наукових праць, присвячених I. Стравінському, нечисленними залишаються роботи, в яких досліджуються його оркестрове мислення та оркестрове письмо. В наявних працях, де науковці звертаються до цієї теми, в центрі уваги постають інструментальні партитури (найчастіше «Петрушка» та «Весна 
священна»). Опери композитора в цьому аспекті спеціально не досліджувались, а питання оркестровки в них порушувались фрагментарно. Проблема часу і простору в музиці композитора вивчалась досить активно (огляд наявних точок зору щодо цієї теми в науковій літературі може бути предметом окремої статті), проте кореляції між просторово-часовою організацією й оркестровкою не спостерігалось. Це зумовлює актуальність пропонованої статті. Матеріалом дослідження обрано оперу «Соловей», позначену стилістичним зламом, що виявляється, зокрема, на рівні оркестровки.

Опера «Соловей» І. Стравінського в науковій літературі досліджена в різноманітних аспектах. Б. Асаф'єв, охоплюючи панорамним поглядом різні параметри та складники опери, підкреслює в ній роль мальовничості, звукопису [1, с. 76], «свята й святковості» [1, с. 85] в широкому розумінні. Акцентом на картинності, імпресіоністській жанровості, пишноті інструментальних фрагментів та констатацією відсутності драматичної дії в цілому вичерпуються спостереження автора стосовно просторово-часової організації опери.

«Соловей» у монографії М. Друскіна [4] не стає предметом спеціального розгляду, а згадується пунктирно в контексті кількох розділів-есе, присвячених різним аспектам творчості композитора. Проте узагальнювальні спостереження автора щодо театральних жанрів у творчості I. Стравінського у цілому є досить цінними, такими, що виводять на проблематику просторово-часової організації опер та балетів композитора, зокрема й досліджуваного нами твору. Так, М. Друскін зауважує, що однією з ключових ідей реформаторських пошуків у сфері музичного театру початку XX ст. було роз'єднання музично-сценічних елементів. I. Стравінський був першим композитором, хто став реалізовувати цю ідею на практиці [4, с. 66-68]. На нашу думку, нові ідеї прокладали шлях до пошуку інноваційних принципів організації, з одного боку, сценічного простору, з іншого - музичного часопростору в оперному та балетному жанрах (значно завдяки тематизму, драматургії та оркестровці).

Роз'єднання елементів вистави парадоксальним чином поєднується в І. Стравінського з великим синтезом. М. Друскін підкреслює значення зорових вражень, що сприяє закладенню «видимого» в музику І. Стравінського: «Зриме» і «слухове» неподільно злиті у Стравінського...» [4, с. 85]. «... «Зриме» при- 
ховано, латентно міститься у всій його музиці, тому, зокрема, так охоче хореографи звертаються до сценічної транскрипції оркестрових, не для театру написаних творів Стравінського» [4, с. 85]. Цю думку підтверджує також А. Баєва: «Стравінський робить зримими всі складові елементи вистави» [2, с. 71]. Безпосередньо, на перший погляд, не стосуючись проблеми просторово-часової організації театральних жанрів, ця теза спонукає до роздумів щодо засобів утілення «зримого», виводячи на питання типу тематизму та оркестрових засобів його об'єктивації в часі та просторі, на питання виявлення пластичності та просторовості в оркестровій фактурі.

Ще однією опорною для нашої статті тезою М. Друскіна $є$ думка щодо підкреслення концентрації вираження в театральних жанрах: «...не мініатюризм форми, а саме конденсоване вираження драматургії, яка закладена в самій музиці» [4, с. 76]. Наведена думка, яка корелює з ідеєю С. Савенко [8] про концентрацію завдяки техніці мотивних структур, виводить на ідею підвищеної подієвості у часі, щільності музичних подій як типологічну ознаку стилю І. Стравінського на різних етапах творчої еволюції. Підвищена подієвість та концентрація вираження досягаються різноманітними засобами: уже названою мотивно-тематичною роботою, «швидкою» кадровою драматургією, а також особливим оркестровим письмом на основі принципу багатофігурності [9].

Нарешті, М. Друскін наголошує на важливості ігрового начала у творчості композитора, якому адекватно відповідає іманентна театральна видовищність та святковість, що зумовлювало стійкий інтерес композитора до музично-сценічних жанрів [4, с. 84-85]. Це положення наштовхує на думку щодо оркестровки як одного із засобів створення особливого театрального (сценічного) часопростору, відзначеного ознаками святковості, особливої атмосфери піднесеності над реальною буденністю, майстерною виробленістю, штучною витвореністю, що відмежовує світ театральний, світ мистецтва від реальності, яка оточує людину. Ігрове $=$ штучне $=$ майстерне (в естетичному смислі) втілюється в І. Стравінського в оркестровому письмі завдяки принципам багатофігурності, комбінаторності, комплементарності та пластичності, що діють у всіх координатах оркестрової фактури.

У контексті міфотворчості в музичному театрі XIX-XX ст. розглядають оперу «Соловей» I. Іванова та А. Мізітова, наго- 
лошуючи, що «Стравінський (як учень Римського-Корсакова) наслідує його інтерес до казки, однак інтерпретує цей жанр відповідно до сучасних уявлень про його духовно-змістові можливості. Це дозволило композиторові «стягнути» в «Солов'я» багатоманітний художній досвід, наблизивши тим самим казку до міфу» [5, с. 7]. Оперування композитором комплексом стійких лексичних одиниць, які в оперній практиці закріпилися за певним типом образності [5, с. 8], не призводить до еклектичної барвистості, а, за слушним зауваженням авторів, «організується завдяки ігровому способу відбиття світу, за якого множинність різнорідних компонентів - умова переключення в різні драматургічні плани (точки зору)» [5, с. 9]. Відповідно, у творах, які спираються на логіку міфу і в яких «пересування» з одного художнього простору в інший виявляються спорідненими з випробуваннями та мандрами казково-міфологічних героїв» [5, с. 9], вибудовується особливий часопростір: часопростір міфу, в якому порушується однолінійна спрямованість часу й гомогенність простору [5, с. 9]. Зауважимо, що описане переключення в різні образно-стилістичні семантичні сфери, які уподібнюються переходам у різні семантичні площини міфу, супроводжуються змінами в тембро-фактурному оформленні тематизму, котрі посилюють ефект якісного зсуву, перетину смислової межі. Тим самим оркестровка в комплексі 3 інтонаційністю відіграє ключову роль у створенні й окресленні специфічними засобами локального семантичного часопростору персонажів та ситуацій (Рибалки, Солов’я, Імператора, Смерті, придворних).

Грунтовне дослідження опери «Соловей», зокрема щодо специфіки організації часу та простору, здійснено в монографії А. Баєвої. Авторка спирається на деякі положення роботи М. Друскіна, плідно розвиваючи їх, одночасно формулює власні оригінальні наукові положення. Особливості опери I. Стравінського, на іiі думку, визначаються загальними властивостями модельованого матеріалу в співвіднесенні з рисами індивідуального стилю композитора [2, с. 55]. У ролі художньо-естетичних систем, які виконали функцію моделей у «Солов'і», дослідниця називає лубок, орнамент, китайський та японський живопис, східну поезію та театр [2, с. 55]. Названі моделі становлять художні полюси тяжіння для «світомистецтва» (російською «мирискусничества») та, ширше, мистецтва модерну, що дозволяє з повним 
правом назвати «Солов'я» оперою свого часу. Орієнтація на такі моделі визначає специфіку організації часу та простору в ній. А. Баєва зауважує: «У «Солов’ї очевидна тенденція до створення багатошарової композиції, основаної на порівняному структурному відокремленні, тісній взаємодії окремих епізодів, сцен, грі тлом та переднім планом, що приводить до множинності глядацьких позицій. М. Друскін називає таку композицію багатоцентровою (за аналогією до живописних творів, побудованих за принципом так званої зворотної перспективи з притаманним їй складовим характером організації простору), зауважуючи, що важливішою іiі особливістю стає сполучення частин на основі тотожності, повтору, перехресних зав'язків і паралелізмів» [2, с. 56]. Установка на графічність, лінію, орнаментальність, видовищність, пластичність (за словами А. Баєвої, «культова для модерну ідея лінії» [2, с. 56]) визначають домінування мальовничості та «декоративної площинності побудов» [2, с. 46], сприяє також особливому протіканню часу в опері. А. Баєва говорить, що в ній «зростає роль статичних моментів, власне дія відсувається на другий план, внутрішній розвиток тієї чи іншої образної сфери замінюється барвистим описом-показом. Так, виникає особливе відчуття часу, немовби застиглого в стоп-кадрі (що не байдуже естетиці мистецтва модерн)» [2, с. 26]. Слушні спостереження авторки монографії стосовно специфіки організації часу та простору в опері «Соловей» підкріплюються аналітичними фрагментами, в яких досліджено мовно-стилістичні засоби, застосовані композитором, з окремими акцентуаціями на прийомах оркестровки.

Таким чином, виходячи з аналізованої літератури, можна зробити висновок, що оркестрове письмо ${ }^{1}$ I. Стравінського як

1 З'ясуємо, який смисл ми вкладаємо в поширене, але мало розроблене поняття «оркестрове письмо». Його визначення міститься в монографії С. Коробецької: «Оркестрова техніка (або оркестрове письмо) - це конкретний вияв тих чи інших технологічних прийомів використання інструментальних тембрів та фактурних оркестрових засобів, спрямованих на творчу реалізацію композиторського задуму, на вирішення творчого завдання. Правила оркестровки - це, по суті, правила оркестрової техніки» [6, с. 62]. Загалом, погоджуючись 3 автором, пропонуємо власне визначення, в якому закцентуємо декілька моментів: 1) важливість індивідуально-стилістичного начала; 2) детермінованість музичною мовою композитора; 3) пов'язаність із просторово-часовими відносинами. Отже, орке- 
засіб об'єктивації уявлень про час та простір в опері «Соловей» не має грунтовного розгляду.

Мета статті полягає у дослідженні прийомів оркестрового письма в опері І. Стравінського «Соловей» як індивідуальної системи технологічних прийомів і принципів, спрямованої на об’єктивацію певних просторово-часових відносин у тембро-фактурній структурі твору.

Наукова новизна роботи полягає: 1) у дослідженні засобів оркестрового письма в опері «Соловей» у контексті стилістичного зламу; 2) у компаративному дослідженні прийомів оркестрового письма «Хмар» К. Дебюссі й I акту «Солов'я»; 3) у виявленні специфіки оркестрового письма в II та III актах опери як засобу об'єктивації просторово-часових відносин.

У статті застосовані такі методи дослідження: функціональний для розкриття специфіки організації оркестрової тканини; компаративний для порівняння особливостей оркестрового письма К. Дебюссі та І. Стравінського; стильовий для виявлення індивідуальних стильових рис I. Стравінського у сфері оркестровки на тлі загальних тенденцій розвитку оркестрового мислення першої половини XX ст.

Виклад основного матеріалу. Опера «Соловей» написана композитором протягом 1909-1914 рр. Робота переривалась створенням балетів на замовлення С. Дягілєва, що відбилось на характері іiі матеріалу. Майже всі дослідники, хто звертався до цього твору, вказують на стилістичну нерівноцінність І-го та наступних двох актів [1; 2; 10 та ін.], зводячи витоки І-го до музики К. Дебюссі та М. Римського-Корсакова $[10$, с. 43] та знаходячи у II-му та III-му актах маніфестацію «справжнього» І. Стравінського, яким він склався в роботі над балетним жанром. Повернення до опери після досвіду балету відбилась на інструментальному оркестровому письмі. Балет не випадково приваблював композитора протягом усього творчого шляху (і ця тема $є$ досить проартикульованою в науковому дискурсі, тому в контексті нашої статті

строве письмо - це детермінована музичною мовою композитора і загально-базовими правилами оркестровки індивідуальна система технологічних прийомів і принципів, спрямованих на об'єктивацію певних просторово-часових відносин у тембро-фактурній структурі твору, зумовленою стильовими, жанровими чинниками й художнім задумом, завдяки функціональній взаємодії оркестрових партій по горизонталі та вертикалі. 
закцентуємо деякі моменти). Музика І. Стравінського проникнута особливою стихією танцю, танцювальністю в широкому смислі: «Навіть його небалетні твори мають чітко виражені, непереборні імпульси танцювального руху» [3, с. 263]. Не випадково близько сорока симфонічних творів композитора отримали хореографічну інтерпретацію, а до балету він відчував особливу пристрасть, про що свідчить кількість балетних партитур [4, с. 73]. М. Друскін наводить висловлювання самого композитора, де той пояснює своє тяжіння до балету, підкреслюючи домінування в класичному танці «вдумливої композиції над розпливчатістю», «правила над свавіллям», «порядку над випадковістю» [4, с. 73] - тих смислових констант, які пронизують творчість І. Стравінського. У балеті композитор знайшов умови для адекватної, всебічної реалізації, іманентно властивої його музиці пластичності, яка походить від особливого відчуття часу (подієвого, пружного, інформаційно насиченого) та простору (неоднорідного, багатоскладового, в якому поєднуються кілька зорових фокусів). У балеті рух, лінія, жест, пластика інтонаційно та темброво-фактурно об'єктивуються, адекватно втілюються у звукоматерії. Тому після досвіду роботи в балеті оркестрове письмо в II-му та III-му актах «Солов'я» є власне «простравінським», хоча, як ми побачимо з аналізу оркестровки І-го акту, риси такого письма проступають уже в його межах.

Звукоматерія І-го акту опери «Соловей» відсилає до імпресіоністського інструментального письма. А. Баєва навіть безпосередньо вказує на прототип, зауважуючи, що «основу оркестрового вступу становлять тематичні та фактурні елементи «Хмар» Дебюссі [2, с. 42]. У цьому творі оркестрове письмо характеризується такими особливостями: 1) застосуванням прийомів, які сприяють створенню широкого простору в оркестровій фактурі; 2) стиранням функціональної межі між тлом та рельєфом; 3) одночасним сполученням невеликої кількості різнофункціональних елементів, що не ускладнює функціональної будови оркестрової тканини по вертикалі; 4) зчепленням варіантів основних тематичних елементів по горизонталі, що надає відчуття постійного оновлення у часі за умов збереження стійкого образу-інваріанта; при цьому - націленістю на утворення горизонтальної континуальності за рахунок утримання основних тематичних елементів (фігури «тла» в різноманітних варіантах та комбі- 
націях та другого тематичного елементу, що звучить в англійського ріжка).

Почергово розглянемо названі пункти. Темі простору та просторовості в музиці К. Дебюссі присвячено чимало праць, адже музичний простір осмислюється як категорія, яка має стилеутворювальне значення у творчості композитора [7, с. 6]. Залишимо зараз їх аналіз за межами нашої статті, лише закцентуємо увагу на роботі С. Мозгот [7]. Авторка зауважує, що проблема просторовості в музиці французького композитора на фонетичному рівні пов'язана з «художньо-просторовими якостями звуку», а саме з масою, об'ємом та щільністю [7, с. 12-13]. Не розглядаючи фортепіанну та оркестрову музику окремо, дослідниця подає комплекс напрацьованих композитором прийомів подолання, «нівелювання» маси звуку та роботи з об’ємом і щільністю, серед яких - «полегшення» звуків нижнього регістру за допомогою staccato [7, с. 12]; використання сурдин, трелей, tremolo, флажолетів, divisi (in 4, б); віддання переваги динаміці pp, штрихам sur la louche i sur le chevalet, pizzicato [7, с. 13]. Спираючись на положення названої роботи, виокремимо саме прийоми оркестрового письма для створення широкого простору в «Хмарах»: 1) застосування прийому divisi в партіях струнно-смичкових інструментів (div. a3, a4, ab); 2) прописаність окремих партій дерев'яних духових, навіть за умов їх еквіритмічного руху; 3) «зняття», «приховання» басової функції; 4) зіставлення оркестрових груп у просторі; 5) зосередженість на тривалому звучанні окремих акордів; 6) застосування багатозвучних комплексів (6-8 звуків із прямим та/або перехресним розташуванням), що охоплюють великий обсяг звучання (двітри октави); 7) дублювання ліній у дві октави, що утворює їх просторове потовщення; 8) віддання переваги середньому та високому регістрам; 9) уникнення низького регістру в партіях контрабасів та фаготів; виключення зі складу оркестру «важкої міді».

Смислова навантаженість і значущість усіх тематичних елементів у звукоматерії «Хмар» свідчить про тематизацію всієї тканини. Перший елемент, який викладається у кларнетів та фаготів у рівномірному русі чвертями, немовби претендує на функцію тла через інтонаційну «стертість» та «невиразність». Проте цілеспрямована робота композитора з цим елементом протягом твору, яка полягає у фактурно-тембрових, регістро- 
вих - просторових - модифікаціях інваріанта, свідчить про вивід його із зони «тло». 3 іншого боку, цьому сприяє й нівелювання інтонаційної яскравості рельєфу, який виокремлюється завдяки тембру та ритму. Другий тематичний елемент звучить у середньому регістрі англійського ріжка, що одразу маркує його тембрально. Виокремленню елементу сприяє й ритмічне оформлення $з$ тріольним зачином. Водночас щодо інтонаційної виразності цей елемент навіть «програє» першому «фоновому». Найбільш яскравим у ньому $є$ «зачин» із тріольним ритмом в обсязі зменшеної кварти, наступний пошаблевий рух $є$ менш виразним порівняно з інтервальними ходами «тла».

Стирання межі між тлом та рельєфом є свідченням того, що функціональна будова оркестрової тканини виявляє тяжіння до порушення класичної ієрархії (мелодія - супроводжувальні голоси), що сприяє переосмисленню, якісній перебудові оркестрового простору. Актуалізація об'єму та просторовості відбувається не за рахунок функціональності шляхом вибудовування ієрархічного простору з чіткою диференціацією елементів на першо- та другорядні з точки зору функцій (на кшталт прямої перспективи в живописі), а в умовах нівелювання різниці між тлом та рельєфом за рахунок інтенсифікації колористично-фонічних потенцій елементів та параметрів оркестрової тканини (регістрів, динаміки, типу розташування акордів, штрихів тощо). Тут доречно провести аналогію з імпресіоністським живописом, у якому порушується пряма перспектива й відкриваються інші механізми організації простору картини.

В оркестровій вертикалі «Хмар» не виявляється тяжіння до функціональної багатоелементності, навіть за умов звучання великої кількості партій. Оптимальна кількість функціональних елементів у партитурі - два-три, що забезпечує легкість та необтяженість оркестрової звукоматерії.

Варіантна робота з тематичними елементами по горизонталі відбувається значно шляхом темброво-регістрово-фактурних перетворень, яким вони підлягають у просторі та часі. Так, формується статично-динамічний час, насичений інформативними зсувами-подіями, які не створюють динамічних якісних смислових «стрибків», проте сприяють відчуттю тяглості-континуальності зі збереженням інваріантного образу, який розгортається у просторі (темброво-регістрово-фак- 
турними засобами) багатьма своїми площинами. Утримання основних тематичних елементів утворює горизонтальну континуальність, їх постійне оновлення - насичену подієвість часу, робота з ними в оркестровій фактурі - просторовість звукоматерії.

Оркестрове письмо в І-му акті «Солов'я» виявляє схожість із «Хмарами» К. Дебюссі за такими ознаками: 1) вибудовування просторової звукоматерії; 2) стирання межі між тлом та рельєфом; 3) одночасне сполучення невеликої кількості різнофункціональних елементів; 4) утримання континуальної горизонталі за рахунок варіантної роботи з мотивними інваріантами.

Проте за умов детального аналізу партитури I. Стравінського крізь візуальну близькість із партитурою французького композитора проступають індивідуальні особливості оркестрового письма. Розглянемо вступ. Вибудовування просторової звукоматерії в І. Стравінського не виключає широкого задіяння низького регістру і може реалізуватися через регістрові, темброві або темброво-регістрові зіставлення у просторі (ц. 2-4 т. і далі). Внутрішня організація першого «фонового» тематичного елементу є складнішою за рахунок нестабільної кількості голосів, що зумовлено більшою тембральною барвистістю й розірваністю, ніж у К. Дебюссі, у партитурі якого перший тематичний елемент утримується в групі струнно-смичкових інструментів після експонування його в дерев'яних духових. Стійкість тембро-звукообразу першого елементу в К. Дебюссі сприяє континуальності, триванню часу, тоді як темброві зі- та протиставлення в I. Стравінського ведуть до виявлення просторового начала, переривають горизонтальну континуальність часу. Однорідність часу у середині першого елемента порушується в І. Стравінського через часовий зсув (запізнення на одну шістнадцяту) щодо тактової риски партій альтів, що диференціює, на перший погляд, однорідну тканину по вертикалі та горизонталі, у часі та просторі (див. від ц. 3).

На стиранні межі між тлом та рельєфом у партитурі «Солов'я» в цілому, а не лише у вступі, як наголошує А. Баєва, корелюючи цю особливість 3 естетикою «світомистецтва» («мирискусничества») та площинним живописом. «У першій частині вступу образ немовби розчинений у навколишній атмосфері, тло набуває значення теми» [2, с. 44]. I далі сто- 
совно китайського маршу в II акті: «Характер взаємозв'язку між тематичними та фоновими елементами зумовлений рухливістю, незакріпленістю функцій фону та переднього плану. (Тут знову виникають аналогії з живописною композицією, яка має нелінійну перспективу й об'ємність утілення і відрізняється площинним трактуванням простору)» [2, с. 47-48]. Зауважимо, що стирання межі між тлом та рельєфом, яке супроводжується нівелюванням, а іноді й руйнацією функціональної ієрархічної супідрядності елементів тканини, в I. Стравінського, як і в К. Дебюссі, зумовлено відходом від законів класико-романтичної музичної мови. Тематизація тла приводить до тематизації та деталізації всієї тканини, ретельної тембральної та фактурної обробки всіх елементів оркестрової фактури. Це позначається на функціональній будові оркестрової тканини, яка корінним чином переосмислюється. Таку особливість не можна вважати виключно рисою оркестрового мислення імпресіоністів або І. Стравінського. Йдеться про одну з провідних тенденцій розвитку оркестровки в музиці XX ст.

Зі вступом вокальної партії (Рибалка) все більше проступають риси саме «простравінського» оркестрового письма, його «почерк». Майже в кожній партії (ц. 8-10) виявляються ритмічно виділені «фігури», ступінь інтонаційної характерності яких простягається від низької до досить виразно-опуклої. Із таких фігур тчеться оркестрова тканина, в якій присутні традиційні функції, вирішені цілком індивідуально внаслідок застосування техніки багатофігурного оркестрового письма. Так, бас є розщеплено-подвоєним (контрабас та литаври), достатньо рухливим в обох партіях, мелодизованим і індивідуально ритмізованим у контрабаса. Гармонійний шар тканини (струнно-смичкові інструменти) побудований за принципом комплементарного сполучення фігур у різних партіях. Англійський ріжок та I кларнет іn В (від ц. $8+4$ т. до ц. $8+9$ т.), що за ритмічною та інтонаційною виразністю можуть претендувати на роль мелодійних контрапунктів, теж «зібрані» з остинатно повторюваних фігур. Ритмічно примхливий (унаслідок зсуву щодо тактової риси) короткий мотив у I гобоя, стертий інтонаційно (висхідна секунда), через своє ритмо-часове маркування «дотягується» до простої фігури. Те ж саме стосується й гармонії-педалі в арфи, опуклість фігурі якої надає стрибок квінт із великої в малу октави. Слід зауважити, що функціональна будова 
оркестрової тканини в межах структурного розділу (заспіву) не змінюється: в ц. 8+10 т. функцію з контрапункту на педаль змінює англійський ріжок, додається з мелодійно рухливою педаллю II кларнет. Загалом утворюється досить статична картина за рахунок остинатного повторення фігур. Проте їх дрібна ритміка й комплементарне сполучення по вертикалі створює ілюзію руху, коливання, широкого простору, повітряності, а по горизонталі - відчуття насиченої подієвості часу завдяки різноманітності ритмічно-інтонаційного вирішення та рухливості фігур; континуальності через їх остинатне утримання.

Зі зміною структурного розділу змінюється й принцип організації оркестрової тканини. У приспіві пісні Рибалки (ц. 10) вона розшаровується надвоє: гармонійне тремолювальне тло утворюють струнно-смичкові інструменти, тоді як I гобой та англійський ріжок послідовно імітують мотиви вокальної партії, множачи їх по вертикалі, що є ще одним (більш традиційним) засобом розширення простору. У ц. 11+1 т. оркестрова тканина ненадовго перетворюється на цілком фонову (гармонійну), позбавлену виразності окремих партій, проте таких фрагментів у партитурі «Солов'я» небагато, а після повернення до роботи над II актом такі фрагменти відсутні.

Оркестрове письмо в II-му та III-му актах позначене більшою складністю в організації простору та більш інтенсивною подієвістю часу. Звернемось до Китайського маршу. А. Баєва акцентує в марші виниклий ефект «декоративної площинності зображення» [2, с. 46], зауважуючи, що основним засобом розвитку $\epsilon$ «варійоване розташування тотожного матеріалу на різних рівнях простору» [2, с. 46]. Це разом із композицією в цілому та структурним оформленням націлено на зняття динаміки й підкреслення статики [2, с. 46]. Погодимось із цією думкою лише частково, адже вона правомірна на макрорівні всієї композиції. Справді, марш картинно-декоративний, а звідси й живописно-площинний через відсутність якісних змін матеріалу та домінування варіантних принципів його розвитку. Однак оркестрова тканина зсередини не виявляє ознак площинності, а іiі простір об'ємний і складно організований завдяки наявності великої кількості елементів. Багатоелементність тканини виникає через взаємопов'язані чинники: 1) застосування тембрових мікстів (при цьому іноді темброве подвоєння) є інтонаційно-ритмічним варіан- 
том основної лінії; 2) розщеплення (подвоєння) оркестрових функцій, часто завдяки ритмічним варіантам або неповним дублюванням; 3) дії принципу багатофігурності; 4) тематизації тла через надання йому інтонаційної та ритмічної рельєфності, що є наслідком реалізації принципу багатофігурності; 5) дії принципу комплементарності по вертикалі та діагоналі, що впливає на щільність оркестрової тканини й зумовлює особливу дискретно-переривчасту ії графіку.

Висновки. Описане на прикладі Китайського маршу оркестрове письмо, позначене індивідуально-стильовими рисами, склалося в ранніх балетах композитора, проте виднілося вже в I-му акті опери. Від імпресіоністської техніки оркестрового письма воно відрізняється: 1) меншою континуальністю за рахунок частішої зміни тембрів та тембрових мікстів; 2) більшою дискретністю та переривчатістю як в організації простору, так і в часовому вимірі через принцип комплементарності у поєднанні елементів по вертикалі та діагоналі та принципу багатофігурності, що дозволяє «згортати» час на різних рівнях партитури (в різних партіях, що виконують різноманітні оркестрові функціi) в енергетичні «згустки», які нанизуються на континуальну часову вісь шляхом остинатного або остинатно-варіантного повтору. Це надає часу підвищеної подієвості, інформаційної насиченості за умов стабільності внаслідок якісної незмінності елементів, що сприяє виникненню так званої «динаміки всередині статики» [2; 4]; 3) багатоелементністю, яка часто виникає через розщеплення основних оркестрових функцій.

Деякі принципи оркестрового письма імпресіоністів розвиваються І. Стравінським цілком оригінально згідно з індивідуально-стильовими настановами. У його оркестровці знаходять продовження: 1) моделювання різноякісного оркестрового простору, що не суперечить зауваженням науковців стосовно площинної картинності [2; 4], яка, на нашу думку, виявляється на макрорівні всієї композиції; 2) стирання межі між тлом та рельєфом, що є наслідком тематизації музичної тканини.

Різницю між оркестровим письмом І-го та наступних актів можна звести до таких положень: 1) оркестрове письмо в I-му акті більше підпорядковується ідеї горизонтальної континуальності за рахунок утримання певного типу оркестрової фактури та тембрів; 2) в оркестровому письмі I-го акту фрагментарно застосовується тип «супроводжувальної» голос фактури, 
яка мало тематизована, у якій відсутня багатофігурність і яка, власне, є варіантом традиційної гармонійної фігурації; 3) в оркестровій тканині І-го акту наявна невелика кількість оркестрових функцій; 4) одночасно в оркестровому письмі I-го акту виявляються риси більш пізнього оркестрового письма композитора (принципи багатофігурності, комплементарності, комбінаторності; розщеплення оркестрових функцій).

Зважаючи на недостатню вивченість теми оркестрового письма в оперних творах I. Стравінського, автор бачить перспективним іiі подальше дослідження на прикладі «Царя Едіпа» та «Пригод гульвіси».

\section{СПИСОК ЛІТЕРАТУРИ}

1. Асафьєв Б. Книга о Стравинском. Ленинград : Музыка, 1977. $279 \mathrm{c}$.

2. Баева А.А. Оперный театр И.Ф. Стравинского. Москва : КРАСАНД, 2009. 304 c.

3. Баланчин Дж. Танцевальный элемент в музыке Стравинского. И.Ф. Стравинский. Статьи. Воспоминания. Москва, 1985. С. 261-269.

4. Друскин М. Игорь Стравинский. Личность, творчество, взгляды. Исследование. Ленинград : Советский Композитор, 1982. $208 \mathrm{c}$.

5. Иванова И.Л., Мизитова А.А. Интерпретация оперного жканра в твориеской практике И. Стравинского : методические рекомендации по курсу истории зарубежной музыки. ХИИ им. И.П. Котляревского. Харьков, 1990. 22 с.

6. Коробецька С. Ю. Оркестровий стиль: теорія, історія, сучасність: Монографія. Київ : Видавництво НІТУ ім. М. Драгоманова, 2011. $332 \mathrm{c}$.

7. Мозгот С.А. Музыкальное пространство в творчестве Клода Дебюсси : автореф. дисс. ... канд. искусствоведения : 17.00.02. Саратов, 2006. $23 \mathrm{c}$.

8. Савенко С. Мир Стравинского. Москва : Композитор, 2001. $327 \mathrm{c}$.

9. Савченко Г. С. Багатофігурність оркестрового письма як принцип організації часу і простору в оркестрових творах I. Ф. Стравінського (від ранніх балетів до Симфонії іn $\mathrm{C}$ та Симфонії у трьох частинах). Аспекти історичного музикознавства. Харків, 2019. Вип. 16. С. 242-258. doi: 10.34064/khnum2-1614.

10. Ярустовский Б.М. Игорь Стравинский. Ленинград : Музыка, 1982. $264 \mathrm{c}$.

\section{REFERENCES}

1. Asaf'ev, B. (1977). Kniga pro Stravinskogo [Book of Stravinsky]. Leningrad : Muzyka, 279 [In Russian]. 
2. Baeva, A. A. (2009). Opernyy teatr I. F. Stravinskogo [Opera theater of I. F. Stravinsky]. Moscow, 304 [In Russian].

3. Balanchin, Dzh. (1985). Tantsevalnyy element v muzyke Stravinskogo [Dance element in Stravinsky's music]. I. F. Stravinsky. Article. Memories, 261-269 [In Russian].

4. Druskin, M. (1982). Igor' Stravinskij. Lichnost', tvorchestvo, vzglyady'. Issledovanie. [Igor Stravinsky. Personality, creativity, views. Study.]. Leningrad : Sovetskij Kompozitor, 208 [in Russian].

5. Ivanova, I. L., Mizitova, A. A. (1990). Interpretatsiya opernogo zhanra $v$ tvorcheskoy praktike I. Stravinskogo [Interpretation of opera genre in creative practice of $И$. Stravinsky]. Kharkiv Institute of Arts named I. P. Kotlyarevsky, 22 [In Russian].

6. Korobecz'ka, S. Yu. (2011). Orkestrovij stil’: teori'ya, i’stori'ya, suchasni'st': Monografi'ya [Orchestral style: theory, history, participation: Monographs]. Kiev: Vidavnicztvo NI'TU i’m. M. Dragomanova [In Ukrainian].

7. Mozgot, S. A. (2006). Muzykalnoe prostranstvo v tvorchestve Kloda Debyussi [Musical space is in work of Claude Debussy] (Extended abstract of Candidate's thesis). Saratov L. V. Sobinov state conservatory, 23 [In Russian].

8. Savenko, S. (2001). Mir Stravinskogo [Stravinsky's World]. Moscow: Kompozitor, 327 [In Russian].

9. Savchenko, H. S. (2019). Bahatofihurnist orkestrovoho pysma yak pryntsyp orhanizatsii chasu i prostoru $\mathrm{v}$ orkestrovykh tvorakh I. F. Stravinskoho (vid rannikh baletiv do Symfonii in $\mathrm{C}$ ta Symfonii $\mathrm{u}$ trokh chastynakh) [Orchestral composition multifigure as a principle of time and space organization of Ihor F. Stravinsky's orchestral works (from early ballets to Symphony in C and Symphony in three movements)]. Aspects of historical musicology, 16, 242-258 [In Ukrainian]. doi: 10.34064/ khnum2-1614.

10. Yarustovskiy, B. M. (1982). Igor Stravinskiy [Igor Stravinsky]. Leningrad : Muzyka, 264 [In Russian]. 